\title{
A multicriteria climatic classification system for grape-growing regions worldwide
}

\author{
Jorge Tonietto $^{\mathrm{a}, *}$, Alain Carbonneau ${ }^{\mathrm{b}, 1}$ \\ a EMBRAPA—National Grape and Wine Research Center, PO Box 130-95700-000, Bento Gonçalves, Brazil \\ ${ }^{\mathrm{b}}$ ENSAM - Formation de Viticulture-Oenologie, Montpellier, France
}

Received 1 August 2002; received in revised form 24 June 2003; accepted 12 January 2004

\begin{abstract}
This study concerns firstly the methodology to describe the climate of vineyards, on a macroclimate scale of viticultural regions worldwide. Three synthetic and complementary viticultural climatic indices (potential water balance of the soil over the growing cycle, heliothermal conditions over the growing cycle and night temperature during maturation), validated as descriptors, are used: (1) dryness index (DI) which corresponds to the potential water balance of the soil of Riou's index, here adapted using precise conditions to calculate it, as an indicator of the level of presence-absence of dryness; (2) heliothermal index (HI) which corresponds to Huglin's heliothermal index; (3) cool night index (CI) an index developed as an indicator of night temperature conditions during maturation. These indices are representative of the variability of the viticultural climate worldwide, related to the requirements of varieties, vintage quality (sugar, colour, aroma), and typeness of the wines. A Multicriteria Climatic Classification System (Géoviticulture MCC System) for the grape-growing regions worldwide is formulated based on classes for each of the three climate indices, with elements to explain the results. Three formulated concepts provide the system base: viticultural climate, climatic group and viticultural climate with intra-annual variability (for warm regions with more than one harvest a year in natural climate conditions). The application of the Géoviticulture Multicriteria Climatic Classification System is presented for 97 grape-growing regions in 29 countries. The system is a research tool for grape-growing and wine-making zoning. It also enables work at different levels on the scale, on a world-wide scale or larger - the large grape-growing region, the small grape-growing region, as shown by the studies performed. It allows relating the viticultural climate to the elements of grape quality and the typeness of the wines considering the climatic zone.
\end{abstract}

(c) 2004 Elsevier B.V. All rights reserved.

Keywords: Vineyard; Climate classification; Climate models; Water balance; Zoning

\section{Introduction}

Elements of the $\mathrm{PhD}$ performed by Jorge Tonietto, obtained at the École Nationale Supérieure Agronomique de Montpellier in May 1999.

* Correspondig author. Tel.: +55-54-455-8000;

fax: +55-54-451-2792.

E-mail addresses: tonietto@cnpuv.embrapa.br (J. Tonietto),

carbonne@ensam.inra.fr (A. Carbonneau).

${ }^{1}$ Fax: +33-4-99-61-00-66.
The world of grapes and wines concerns at least 40 countries. The quality and the typeness of wines depend on natural factors and human factors. It is said that, worldwide, the climate of the different grape-growing regions accounts for a large part of the diversity of varieties cultivated, viticultural products, quality and typeness of the wines. 
A diagnosis of the current status of knowledge regarding grape-growing shows that few studies are available on the climate, involving world-wide viticulture as a whole. The climatic indices available to describe the viticultural regions are above all thermal at the level of the grape-growing cycle.

In fact, temperature influences composition and quality of grapes (Coombe, 1987). In California (USA), the Thermal Index of Winkler has allowed the classification, in five large regions, according to the different categories of degrees-days established by this index (Amerine and Winkler, 1944; Winkler, 1962). These regions represent quite well the grape quality and some of the wine characteristics as a result of the climatic influence of this zone. Huglin (1978) has developed the Heliothermal Index of Huglin, which is applicable at a world-wide range, established over a period which is closest to the average cycle of the grapevine. It takes into account the length of the day for the highest latitudes, uses the daily temperatures and displays a good relation to the potential of sugar content of the grape. However, both above mentioned indices remain essentially thermal over the cycle, and are not able to weel distinguish the climates in a world-wide scale because other climatic factors have to be considered.

During the ripening period, the air temperature plays a determinant role for grape maturation, including the aroma and the coloration, having an important effect on the characteristics of the wines (Jackson and Lombard, 1993). The day temperatures influence the coloration, but the effect of conditions of cool nights temperatures on it is even stronger (Singleton and Esau, 1969; Kliewer and Torres, 1972; Kliewer, 1973; Tomana et al., 1979; Fregoni and Pezzutto, 2000).

Different water level in the soil affects grape quality and reflects in wine quality (Conradie et al., 2002). Jackson and Cherry (1988) show that in regions with a high rainfall the ripening capacity of grapes is lower to that predicted by the climatic thermal indices. It is observed that in temperate regions which do not generally suffer droughts, a certain lack of water during the ripening period is favorable to the organoleptic wine quality (Galet, 1993; Riou et al., 1994; Huglin and Schneider, 1998). The regulation of water supply is determinant for obtaining grapes of quality (Seguin, 1983; Mérouge et al., 1998). Bravdo and Hepner (1987) show that a water deficit can improve the quality of the grape, especially at moderate levels (Carbonneau, 1998). Riou et al. (1994) have developed a potential water balance of the soil index for vineyards, related to the grape quality potential for wine, modeled to be used in different macroclimates (Carbonneau, 1994).

Even considering some important descriptions of climate concerning grape-growing regions (Gladstones, 1992; Smart and Dry, 1980; Bentryn, 1988), it may be established that the indices available are still insufficient to provide a uniform climatic description of grape-growing regions and to broaden the understanding of the great climatic variability found in the world vineyards.

As found in different systems used to classify general climates of the world, a multicriteria climatic classification for grape-gowing regions, with synthetic indices related to requirements of varieties, vintage quality (sugar, colour, aroma), and typeness of the wines is lacking. The géoviticulture concept, which corresponds to processing viticultural information on a world scale (Carbonneau and Tonietto, 1998), may appropriate a new way to identify and to compare viticulture climate of the regions, characterize their variability worldwide and establish groups of grape-growing regions, bearing a certain similarity as regards climates. The research presented below provides some answers to these problems.

\section{Methodology for the characterization of the viticultural climate worldwide}

\subsection{Climatic data base for grape-growing regions worldwide}

One of the constraints in performing a study of this kind was the availability of a sufficiently large and representative data base of climate data for world grape-growing regions. For this purpose we worked with the support of the World Meteorological Organization (W.M.O.), and the collaboration of members of the Agricultural Meteorology Commission of each country, and with some scientific institutions.

Regarding the climate, we have used only one point of reference to represent each wine-growing region studied, although it is known that the climate of each region can show important climatic variability. 
Thus, in the text, the word wine-growing region has this connotation regarding its climatic representativity in the corresponding region. The data regarding grape-growing regions from the data base established correspond to the inter-annual monthly means of climatic variables, insofar as possible the normal climatic of the 1961-1990 series (minimum, maximum and mean air temperature, precipitation; relative air humidity; mean wind speed; solar radiation and/or sunshine hours; and Penman's potential evapotranspiration) from a standardized meteorological station that represents the climate of the grape-growing region.

To study the climate, we chose 97 regions from 29 countries (Table 1) with complete data of all climatic variables, with no estimation data. The sample of grape-growing regions is representative of the climatic diversity of world viticulture and those regions were chosen to provide a good geographic distribution (over all 6 of the 7 continents of the globe: latitude between $4^{\circ}$ and $51^{\circ}$ in the Northern Hemisphere and between $6^{\circ}$ and $45^{\circ}$ in the Southern Hemisphere), and to increase the diversity of types of climate represented (oceanic, warm oceanic, transition temperate, continental, cold continental, mediterranean, subtropical, continental subtropical, attenuated tropical, arid and hyperarid climates and borders of arid and semiarid climates-classified according to Peguy, 1970) and their variability.

The research covers regions where the grape is cultivated on a commercial scale for the production of wine. The regions where grapes are not cultivated are, therefore not included in this study, even if some of them present a wine-growing potential. But, in order to have an overall view of the world vineyards, some regions located at the high latitude limits of grape cultivation and also regions in the intertropical zone-desert climates and tropical climates-were also included, even if they do not produce much wine.

\subsection{Climatic indices to characterize the climate of grape-growing regions}

The climatic indices presented below are the result of a preliminary study that allowed us to test their pertinence on a large data base including the regions presented in Table 1 and others. Thus, three climatic indices were chosen, related to water balance and thermal conditions (heliothermal potential and night temperature).

These indices are established as a function of a mean vegetative cycle of the grape. They are pertinent both to characterize as such the climatic potentials of a region, and strongly linked to the qualitative potential and to the characteristics of the grapes or viticultural products (requirements of varieties, vintage quality - sugar, acidity, colour, aroma, and typeness of the wines). As will be seen below, these three synthetic indices provide complementary information about each other.

\subsubsection{Heliothermal index}

Some reasons led to the choice of the classical Heliothermal Index of Huglin (Huglin, 1978) in this study. In this index, the "helio" component is due, first to the " $d$ " coefficient of the thermal component which expresses the mean day length in relation to the latitude, second to the fact that the calculation of the thermal component is estimated over the mean hemeroperiod when most of metabolisms are active. This provides information regarding the level of heliothermal potential, and is calculated based on a period that is on the average biologically acceptable. It also provides a better idea of the sugar potential according to varieties than the classic temperature sums and, thus, provides qualitative information. Combined with the cool night index (CI, presented further), it permits a good discrimination of the region climate, as regards global heliothermal conditions during vegetative cycle of the grape and cool night conditions during ripening period. All these reasons justify the choice as compared with other indices available, especially the Thermal Index of Winkler which is correlated to it $(r=0.98$ between the Heliothermal Index of Huglin and the Thermal Index of Winkler over the 97 regions of the study as a whole), but less pertinent to the qualitative factors.

Calculation: The Heliothermal Index of Huglin (HI) (Huglin, 1978) is calculated using:

$$
\mathrm{HI}=\sum_{01.04}^{30.09} \frac{\left[(T-10)+\left(T_{x}-10\right)\right]}{2} d
$$

- In the Northern Hemisphere in the above formula, $T$ is the mean air temperature $\left({ }^{\circ} \mathrm{C}\right), T_{x}$ maximum air temperature $\left({ }^{\circ} \mathrm{C}\right), d$ length of day coefficient, 
Table 1

Regions of the database, represented here by one meteorological station (latitude, longitude and altitude according Tonietto, 1999)

\begin{tabular}{|c|c|c|c|c|c|c|c|c|c|c|c|}
\hline \multirow[t]{2}{*}{ Country } & \multicolumn{2}{|l|}{ Région } & \multirow[t]{2}{*}{ Country } & \multicolumn{2}{|l|}{ Région } & \multirow[t]{2}{*}{ Country } & \multicolumn{2}{|l|}{ Région } & \multirow[t]{2}{*}{ Country } & \multicolumn{2}{|l|}{ Région } \\
\hline & Name & Acronym & & Name & Acronym & & Name & Acronym & & Name & Acronym \\
\hline Argentina & $\begin{array}{l}\text { Lujan de Cuyo } \\
\text { General Roca }\end{array}$ & $\begin{array}{l}\text { ARlu } \\
\text { ARri }\end{array}$ & France & $\begin{array}{l}\text { Bordeaux } \\
\text { Carcassonne }\end{array}$ & $\begin{array}{l}\text { FRbo } \\
\text { FRca }\end{array}$ & Italy & $\begin{array}{l}\text { Lecce } \\
\text { Modena }\end{array}$ & $\begin{array}{l}\text { ITle } \\
\text { ITmo }\end{array}$ & Spain & $\begin{array}{l}\text { Cádiz } \\
\text { Rioja }\end{array}$ & $\begin{array}{l}\text { ESje } \\
\text { ESlo }\end{array}$ \\
\hline Australia & $\begin{array}{l}\text { Mildura } \\
\text { Mount Gambier } \\
\text { Nuriootpa }\end{array}$ & $\begin{array}{l}\text { AUmi } \\
\text { AUmo } \\
\text { AUnu }\end{array}$ & & $\begin{array}{l}\text { Cognac } \\
\text { Colmar } \\
\text { Macon }\end{array}$ & $\begin{array}{l}\text { FRcg } \\
\text { FRcl } \\
\text { FRma }\end{array}$ & & $\begin{array}{l}\text { Perugia } \\
\text { Ravenna } \\
\text { Trapani }\end{array}$ & $\begin{array}{l}\text { ITpe } \\
\text { ITra } \\
\text { ITta }\end{array}$ & & $\begin{array}{l}\text { Málaga } \\
\text { Murcia } \\
\text { Orense }\end{array}$ & $\begin{array}{l}\text { ESml } \\
\text { ESmu } \\
\text { ESor }\end{array}$ \\
\hline Brazil & $\begin{array}{l}\text { Bento Gonçalves } \\
\text { Petrolina }\end{array}$ & $\begin{array}{l}\text { BRbe } \\
\text { BRpe }\end{array}$ & & $\begin{array}{l}\text { Montélimar } \\
\text { Montpellier }\end{array}$ & $\begin{array}{l}\text { FRmm } \\
\text { FRmp }\end{array}$ & Japan & $\begin{array}{l}\text { Treviso } \\
\text { Kofu }\end{array}$ & $\begin{array}{l}\text { ITte } \\
\text { JPko }\end{array}$ & & $\begin{array}{l}\text { Tenerife } \\
\text { Tarragona }\end{array}$ & $\begin{array}{l}\text { ESsa } \\
\text { ESta }\end{array}$ \\
\hline Canada & $\begin{array}{l}\text { Québec } \\
\text { Summerland } \\
\text { Vancouver }\end{array}$ & $\begin{array}{l}\text { CAqu } \\
\text { CAsu } \\
\text { CAva }\end{array}$ & & $\begin{array}{l}\text { Nantes } \\
\text { Pau } \\
\text { Perpignan }\end{array}$ & $\begin{array}{l}\text { FRna } \\
\text { FRpa } \\
\text { FRpe }\end{array}$ & $\begin{array}{l}\text { New Zealand } \\
\text { Peru } \\
\text { Portugal }\end{array}$ & $\begin{array}{l}\text { Napier } \\
\text { Ica } \\
\text { Anadia }\end{array}$ & $\begin{array}{l}\text { NZna } \\
\text { PEic } \\
\text { PTan }\end{array}$ & $\begin{array}{l}\text { Switzerland } \\
\text { Thailand }\end{array}$ & $\begin{array}{l}\text { Valladolid } \\
\text { Geneva } \\
\text { Bangkok }\end{array}$ & $\begin{array}{l}\text { ESva } \\
\text { CHge } \\
\text { THba }\end{array}$ \\
\hline Chile & $\begin{array}{l}\text { Curico } \\
\text { Santiago }\end{array}$ & $\begin{array}{l}\text { CLcu } \\
\text { CLsa }\end{array}$ & & $\begin{array}{l}\text { Reims } \\
\text { Toulouse }\end{array}$ & $\begin{array}{l}\text { FRre } \\
\text { FRte }\end{array}$ & & $\begin{array}{l}\text { Évora } \\
\text { Funchal }\end{array}$ & $\begin{array}{l}\text { PTev } \\
\text { PTfu }\end{array}$ & Tunisia & $\begin{array}{l}\text { Chiangmai } \\
\text { Bizerta }\end{array}$ & $\begin{array}{l}\text { THch } \\
\text { TNbi }\end{array}$ \\
\hline China & $\begin{array}{l}\text { Bei Jing } \\
\text { Tong Chuan } \\
\text { Urumqi } \\
\text { Yi Couniy } \\
\text { Yi Li }\end{array}$ & $\begin{array}{l}\text { CNbe } \\
\text { CNto } \\
\text { CNur } \\
\text { CNyc } \\
\text { CNyl }\end{array}$ & Germany & $\begin{array}{l}\text { Toulon } \\
\text { Tours } \\
\text { Freiburg } \\
\text { Geiseinheim } \\
\text { Neustadt }\end{array}$ & $\begin{array}{l}\text { FRtn } \\
\text { FRtr } \\
\text { DEfr } \\
\text { DEge } \\
\text { DEne }\end{array}$ & Rep. of Korea & $\begin{array}{l}\text { Lisbon } \\
\text { Peso da Régua } \\
\text { Viseu } \\
\text { P'ohang } \\
\text { Suwon }\end{array}$ & $\begin{array}{l}\text { PTli } \\
\text { PTpe } \\
\text { PTvi } \\
\text { KRpo } \\
\text { KRsu }\end{array}$ & $\begin{array}{l}\text { Turkey } \\
\text { Uruguay }\end{array}$ & $\begin{array}{l}\text { Nabeul } \\
\text { Tunis-Cartagena } \\
\text { Izmir } \\
\text { Tekirdag } \\
\text { Las Bruxas }\end{array}$ & $\begin{array}{l}\text { TNna } \\
\text { TNtu } \\
\text { TRiz } \\
\text { TRte } \\
\text { UYcn }\end{array}$ \\
\hline Colombia & La Unión & COla & & Stuttgart & DEst & Slovakia & Bratislava & SKbr & USA & Cleveland & UScl \\
\hline England & Maidstone & GBma & & Trier & DEtr & Slovenia & Beli Kriz & SIbe & & Fresno & USfr \\
\hline France & $\begin{array}{l}\text { Agen } \\
\text { Ajaccio } \\
\text { Angers } \\
\text { Bastia } \\
\text { Besançon }\end{array}$ & $\begin{array}{l}\text { Frag } \\
\text { Fraj } \\
\text { Fran } \\
\text { Frba } \\
\text { Frbe }\end{array}$ & $\begin{array}{l}\text { Guatemala } \\
\text { India }\end{array}$ & $\begin{array}{l}\text { Würzburg } \\
\text { Estanzuela } \\
\text { Ludhiana } \\
\text { Pune } \\
\text { Haifa }\end{array}$ & $\begin{array}{l}\text { DEwü } \\
\text { GTes } \\
\text { INlu } \\
\text { INpu } \\
\text { ILha }\end{array}$ & $\begin{array}{l}\text { South Afrique } \\
\text { Spain }\end{array}$ & $\begin{array}{l}\text { Bizeljsko } \\
\text { Murska Sobota } \\
\text { Novo Mesto } \\
\text { Cape Town } \\
\text { Ciudad Real }\end{array}$ & $\begin{array}{l}\text { SIbi } \\
\text { SImu } \\
\text { SInm } \\
\text { ZAca } \\
\text { ESci }\end{array}$ & & $\begin{array}{l}\text { Medford } \\
\text { Portland } \\
\text { Rochester } \\
\text { Sacramento }\end{array}$ & $\begin{array}{l}\text { USme } \\
\text { USpo } \\
\text { USrc } \\
\text { USsc }\end{array}$ \\
\hline
\end{tabular}


Table 2

The coefficient length of day $(d)$ by latitude for the HI index

\begin{tabular}{ll}
\hline Latitude & Length of day coefficient $(d)$ \\
\hline$\leq 40^{\circ} 00^{\prime}$ & 1.00 \\
$40^{\circ} 01^{\prime}-42^{\circ} 00^{\prime}$ & 1.02 \\
$42^{\circ} 01^{\prime}-44^{\circ} 00^{\prime}$ & 1.03 \\
$44^{\circ} 01^{\prime}-46^{\circ} 00^{\prime}$ & 1.04 \\
$46^{\circ} 01^{\prime}-48^{\circ} 00^{\prime}$ & 1.05 \\
$48^{\circ} 01^{\prime}-50^{\circ} 00^{\prime}$ & 1.06 \\
\hline
\end{tabular}

ranging from 1.02 to 1.06 between $40^{\circ}$ and $50^{\circ}$ of latitude (Table 2).

- In the Southern Hemisphere the index is equally calculated based on the 6-month period from 1 October to 31 March.

The index is calculated from monthly climatic means.

\subsubsection{Cool night index}

The cool night index is a night coolness variable which takes into account the mean minimum night temperatures during the month when ripening usually occurs beyond the ripening period. The purpose of this index is to improve the assessment of the qualitative potentials of wine-growing regions, notably in relation to secondary metabolites (polyphenols, aromas) in grapes. That climatic factor is important as regards grape and wine color and aromas (Kliewer and Torres, 1972; Kliewer, 1973; Tomana et al., 1979).

Calculation: The determination of the cool night index (CI) is done as given further (Tonietto, 1999).

- In the Northern Hemisphere: $\mathrm{CI}=$ minimum air temperature in the month of September (mean of minima), in ${ }^{\circ} \mathrm{C}$.

- In the Southern Hemisphere: $\mathrm{CI}=$ minimum air temperature in the month of March (mean of minima), in ${ }^{\circ} \mathrm{C}$.

\subsubsection{Dryness index}

The dryness index (DI) is measured based on an adaptation of the potential water balance of the soil index of Riou (Riou et al., 1994), developed specially for vineyard use.

It enables the characterization of the water component of the climate in a grape-growing region, taking into account the climatic demand of a standard vineyard, evaporation from bare soil, rainfall without
Table 3

Period for the calculation of DI and the value of $W$

\begin{tabular}{llll}
\hline Moment & \multicolumn{2}{l}{ Date in the hemisphere } & Value of $W$ \\
\cline { 2 - 3 } & North & South & \\
\hline Initial moment & 1 April & 1 October & $\begin{array}{l}W=\text { Wo reserve } \\
\text { (estimated } \\
\text { regional mean })\end{array}$ \\
Final moment & 30 September & 31 March & \begin{tabular}{l}
$W=\mathrm{DI}$ \\
\hline
\end{tabular}
\end{tabular}

deduction for surface runoff or drainage. It indicates the potential water availability in the soil, related to the level of dryness in a region. That climatic factor is important as regards the level of grape ripening and wine quality (Jackson and Cherry, 1988; Seguin, 1983; Mérouge et al., 1998; Carbonneau, 1998).

Calculation: The potential water balance index of Riou, here adapted to precise conditions of calculation described below, is called dryness index, and calculated using:

$W=\mathrm{Wo}+P-T_{\mathrm{v}}-E_{\mathrm{s}}$

with, $W$ is the estimate of soil water reserve at the end of a given period, Wo the initial useful soil water reserve, which can be accessed by the roots, $P$ the precipitation, $T_{\mathrm{V}}$ the potential transpiration in the vineyard, $E_{\mathrm{S}}$ the direct evaporation from the soil.

Dryness index (DI) is calculated based on a 6-month period, the same used for HI described above, which is acceptable for most of vineyard in the world. The values of $W$ in the first and last moment, and the initial and final date, according to hemisphere, are reported in Table 3.

In the preceding formula, $T_{\mathrm{v}}$ and $E_{\mathrm{S}}$ are calculated month by month using:

$T_{\mathrm{v}}=\mathrm{ETP} k$

ETP is the potential evapotranspiration (monthly total), using the Penman method (Penman, 1948), $k$ the coefficient of radiation absorption by vine plant (which is in relation to transpiration and depends on vine architecture)

$E_{\mathrm{s}}=\frac{\mathrm{ETP}}{N}(1-k) \mathrm{JPm}$

$N$ is the number of days in the month, JPm the number of days of effective evaporation from the soil per month. 
$\mathrm{JPm}$ is the rainfall per month in $\mathrm{mm} / 5$; JPm should be $\leq$ the number of days per month.

$k$ values adopted as given further.

- In the Northern Hemisphere, $k=0.1$, for April, 0.3 for May and 0.5 for the months from June to September.

- In the Southern Hemisphere, $k=0.1$ for October, 0.3 for November and 0.5 for the months from December to March.

$W$ can be negative, for expressing the potential water deficit, but should not be greater than Wo. The index is calculated month by month, based on monthly values of P, ETP, Tv and Es. DI is called the value of $W$ obtained at the final moment following the rules above and adopting $\mathrm{Wo}_{\mathrm{o}}=200 \mathrm{~mm}$.

\subsection{Classes of viticultural climate and their interpretation}

The adoption of the notion of climatic class to achieve a classification of grape-growing regions is related to the fact that each class can effectively represent not only climatic differences, but also responses of the vine, grapes or its products to climatic factors defined by the index considered. Thus they permit grouping together the most homogeneous grape-growing regions using a multicriteria classification.
The classes proposed for the different viticultural climate index, and their interpretation, based on experience in world-wide viticulture, founded on the study data base, are described below.

\subsubsection{Heliothermal index}

The classes of heliothermal index are presented in Table 4.

The theoretical characteristics for each class of HI climate are:

- HI - 3: the very cool viticultural climate class includes all the regions which are only at the inferior thermal limit for vines; under these heliothermal conditions it is only the very early/early varieties that can reach maturity, especially the white varieties (i.e. Muller-Thurgau, Pinot blanc, Gamay, Gewurztraminer) (for example: Québec, CAqu; Reims, Champagne FRre; Geisenheim, DEge). Under very cold winter conditions, certain regions use interspecific hybrids, or american Vitis which are more resistant than Vitis vinifera.

- HI - 2: in the cool viticultural climate class, the heliothermal potential allows a very large range of varieties of grapes, white or red, to ripen, including for instance Riesling, Pinot noir, Chardonnay, Merlot, Cabernet franc (for example: Tours, Loire Valley, FRtr).

- HI - 1: in the temperate viticultural climate class, the later varieties, such as Cabernet-Sauvignon,

Table 4

Classes of viticultural climate for the dryness index, heliothermal index and cool night index of the grape-growing regions

\begin{tabular}{|c|c|c|c|}
\hline Index & Class of viticultural climate & Acronym & Class interval \\
\hline \multirow[t]{6}{*}{ Heliothermal index, HI } & Very warm & $\mathrm{HI}+3$ & $>3000$ \\
\hline & Warm & $\mathrm{HI}+2$ & $>2400 \leq 3000$ \\
\hline & Temperate warm & $\mathrm{HI}+1$ & $>2100 \leq 2400$ \\
\hline & Temperate & $\mathrm{HI}-1$ & $>1800 \leq 2100$ \\
\hline & Cool & $\mathrm{HI}-2$ & $>1500 \leq 1800$ \\
\hline & Very cool & $\mathrm{HI}-3$ & $\leq 1500^{-}$ \\
\hline \multirow[t]{4}{*}{ Night cold index, CI $\left({ }^{\circ} \mathrm{C}\right)$} & Very cool nights & $\mathrm{CI}+2$ & $\leq 12$ \\
\hline & Cool nights & $\mathrm{CI}+1$ & $>12 \leq 14$ \\
\hline & Temperate nights & $\mathrm{CI}-1$ & $>14 \leq 18$ \\
\hline & Warm nights & $\mathrm{CI}-2$ & $>18^{-}$ \\
\hline \multirow[t]{4}{*}{ Dryness index, DI (mm) } & Very dry & $\mathrm{DI}+2$ & $\leq-100$ \\
\hline & Moderately dry & $\mathrm{DI}+1$ & $\leq 50>-100$ \\
\hline & Sub-humid & DI -1 & $\leq 150>50$ \\
\hline & Humid & DI -2 & $>150$ \\
\hline
\end{tabular}


Ugni Blanc and Syrah can equally reach maturity (for example: Bordeaux, FRbo; Viseu, Dão, PTvi).

- $\mathrm{HI}+1$ : in the temperate warm class of viticultural climate, Grenache, Mourvèdre, Carignan can ripen, for instance. Therefore there is no more heliothermal constraint to ripen all cultivated varieties (except some exceptions such as the seedless varieties) (for example: Nuriootpa, AUnu; Montpellier, Midi, FRmp).

- $\mathrm{HI}+2$ : the warm class of viticultural climate is characterized by a potential which exceeds the heliothermal needs to ripen the varieties, even the late ones (with some associated risks of stress) (for example: Jerez da la Frontera, ESje; Nabeul, TNna).

- $\mathrm{HI}+3$ : in the very warm class of viticultural climate, besides the fact that there is no heliothermal constraint for the grapes to ripen, intertropical zone climates begin to occur for which it is possible, in certain cases, to have more than one harvest a year (for example: Petrolina, São Francisco Valley, BRpe; Ludhiana, INlu).

\subsubsection{Cool night index}

CI provides complementary idea of the thermal regime particularly involved in the grape-ripening period. The generic theoretical characteristics for each class (Table 4) of climate are given further.

- $\mathrm{CI}-2$ : in the warm nights class of viticultural climate, the grape-growing region undergoes a period of grape ripening with high nocturnal temperatures for all varieties, which can affect for instance berry colour and aromatic potential (For examle: Chiangmai - THch; Petrolina, São Francisco Valley BRpe).

- CI - 1: in the temperate nights viticultural climate class, there is an intermediate condition between viticultural climates cool nights and warm nights. The later varieties will ripen under lower night temperature conditions than the early varieties (For example: Jerez de la Frontera - ESje; Évora, Alentejo - PTev).

- CI + 1: in the cool nights viticultural climate class, ripening occurs under conditions that can be more or less cool, depending on how early the varieties are. However, overall, conditions are cooler than in class $C I-1$, so that a maximum threshold of night temperature favorable to ripening will not be ex- ceeded for any variety (For example: Bordeaux FRbo; Anadia, Bairrada - PTan). Tonietto and Carbonneau (1998) found a threshold around $14.2^{\circ} \mathrm{C}$ in relation to berry colour and terpenic aroma intensity.

- $\mathrm{CI}+2$ : in the very cool nights viticultural climate class, night temperature conditions are low and the positive effect of these temperatures depends, above all, on a heliothermal potential that could ensure a good level of grape ripening for a given variety (For example: Santiago do Chile - CLsa; Colmar, Alsace - FRcl; DEfr - Freiburg).

In general, it could be said that under warm night temperature conditions for maturation, the tendency is to observe loss of aromas. The red varieties also are at risk of becoming a relatively light color. On the other hand, cool night temperature conditions for ripening are essentially favorable to the grape colors and aromas. These two characteristics of the grapes are expressed mainly under heliothermal conditions that are sufficient for maturation.

Under the night temperature conditions of the very cool nights class, grapes could be found with a high potential for color and aromas, if full ripening conditions are assured (most of the regions producing well-reputed white wines are in this class of viticultural climate). On the other hand, the potential might be very weak if conditions for good ripening, especially the heliothermal condition, are not assured.

\subsubsection{The dryness index}

Two large groups appear in the forefront: wet and dry regions. These 2 groups are subdivided into classes whose theoretical characteristics are shown further (Table 4).

\subsubsection{Wet climates.}

- DI - 2: it is considered that with an DI above $150 \mathrm{~mm}$, humid viticultural climate class, this class of climate corresponds to "absence of dryness", with a high level of water balance availability, and a tendency to excess in relation to quality and normally best ripening of grapes is find in less humid years (For example: Bento Gonçalves, Serra Gaúcha, BRbe; Freiburg, DEfr; Macon, Bourgogne, FRma). 
- DI - 1: with an DI between 50 and $150 \mathrm{~mm}$, sub-humid class of viticultural climate, the condition is also typical of the "absence of dryness". The value of $50 \mathrm{~mm}$ would be a critical value revealing the introduction of a minimum water balance constraint under conditions of frequent summer dryness and, therefore, a good indicator of the point of change of the condition of water availability in the soil to characterize regions with the presence or absence of frequent dryness (for example: Bordeaux, FRbo; Napier, NZna; Reims, Champagne, FRre).

\subsubsection{Dry climates.}

- DI + 1: in the large "presence of dryness" group, the interval of DI between 50 and $-100 \mathrm{~mm}$, the class of viticultural climate moderately dry presents climatic conditions where vine will potentially face a certain level of dryness. This situation, in which there is a significant stomatal regulation of the plant, is usually favorable to maturation (for example: Montpellier, Midi, FRmp; Funchal, Madeira, PTpe). Irrigation is practiced in certain cases. Around DI $<50 \mathrm{~mm}$ we begin to find regions classified as mediterranean-type climate, with deficit water in the summer.

- DI + 2: At the level below of $-100 \mathrm{~mm}$, very dry class of viticultural climate, potential dryness is already marked, leading to frequent stress effects and in most cases irrigation is currently practiced. The DI below $-200 \mathrm{~mm}$ characterizes regions with a high deficit of available soil water; these are the regions where irrigation is mandatory and there is a frequent risk of severe stress if adequate irrigation is not practiced (for example: Jerez de la Frontera, ESje; Ica, PEic; Nuriootpa, AUnu).

\subsection{Géoviticulture MCC System}

The Géoviticulture Multicriteria Climatic Classification System (Géoviticulture MCC System or Système CCM Géoviticole used in French) is a climatic classification system for grape-growing regions based on the integration of the different classes of the three climatic indices-DI, HI and CI. This establishes the viticultural climate of each region and enables the regions to be classified and grouped. Thus, the system allows the identification of climatic analogues (Fig. 2, Table 5).
Three new definitions have been formulated to use the system.

(a) Viticultural climate: the viticultural climate is the climate of a locality, a vineyard or a grape-growing region, described by the set of three viticultural climatic indices. The viticultural climate is thus established based on climatic and viticultural information, which is more specific than climate according to its general meaning. It should be noted that the viticultural climate of a place changes from 1 year to another, which leads to two sub-definitions: the mean viticultural climate and the range of viticultural climate.

(b) Climatic group: the climatic group to which localities, vineyards or grape-growing regions belong, is an ensemble of localities, vineyards or grape-growing regions that present a same class of viticultural climate. Usually, the climatic group includes a large share of the (inter-annual) ranges of viticultural climates.

(c) Viticultural climate with intra-annual variability: this corresponds to the regions that, under natural climate conditions, change viticultural climate class as a result of the time of the year at which grapes can be produced (a definition to be used for regions with a hot climate where it is possible to have more than one grape harvest a year).

The definition of viticultural climate with intraannual variability is applicable not only, but mainly in the intertropical zone, for regions in which the thermal potential is such that the grapes do not undergo a dormant period, nor vegetative repose classically occurring in regions with a temperate type of climate. The adoption of a certain number of cultivation practices allows more than one harvest a year to be obtained. Sometimes an average of more than two harvests a year can be achieved, with the possibility of distributing the grape harvests to cover all months of the year.

Here it is necessary to know how to analyze and characterize the viticultural climate of these regions which, different from the traditional regions, have more than one harvest a year, and do not always have the same production period. Under these conditions, the viticultural climate of a region may present climatic differences during the time of year under consideration. 
Table 5

Classification of the viticultural climate (mean) of 97 regions by class of climatic viticultural index DI, HI and CI of the Géoviticulture MCC System

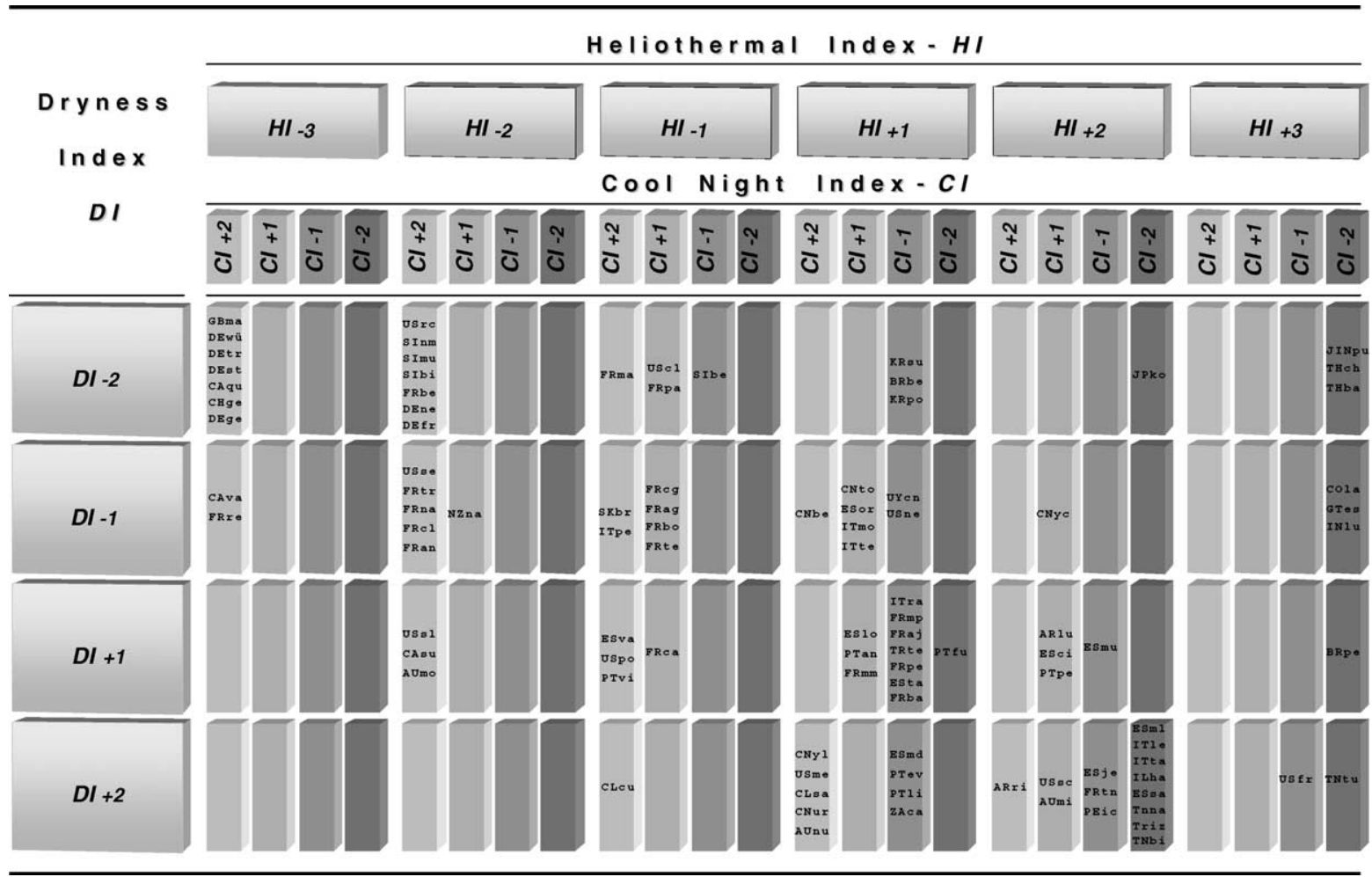

The Géoviticulture MCC System is only applicable to grape-growing regions, since it is applied once the climatic criteria limiting viticulture (risk of frost, excessive humidity, etc.) are taken into account. This concern existing grape-growing areas. But on the other hand, it can contribute to the identification of new regions with a grape-growing potential within the limits of their feasibility. The general scheme showing how the Géoviticulture MCC System functions is presented in Fig. 1. The system can be used for the climatic classification of a grape-growing region, a vineyard, a locality or viticultural terroir. With a climate data base observed or even modeled concerning the grape-growing region, we can calculate the viticultural climatic indices HI, CI and DI and determine the viticultural climate (mean or range) or the viticultural climate with intra-annual variability. This information allows us to determine the class of viticultural climate (classification), the climatic group and the position of the grape-growing region as regard to other regions and climatic groups (Fig. 2). Insofar as the Géoviticulture MCC System enables an improved description of the viticultural climate and the study of its effect on the quality of the grape and typeness of the wines, it provides a contribution to zoning viticultural research (Tonietto, 2001).

\section{Results}

\subsection{Macroclimatic variability of world vineyards}

The results of 3 climatic indices calculated based on all the 97 regions of the study (dryness index, heliothermal index and cool night index), showed the great world climatic variability, both by the HI, which is already well known for its use as a climatic index in world viticulture, and for the DI and for the CI (Fig. 2, Table 5). 


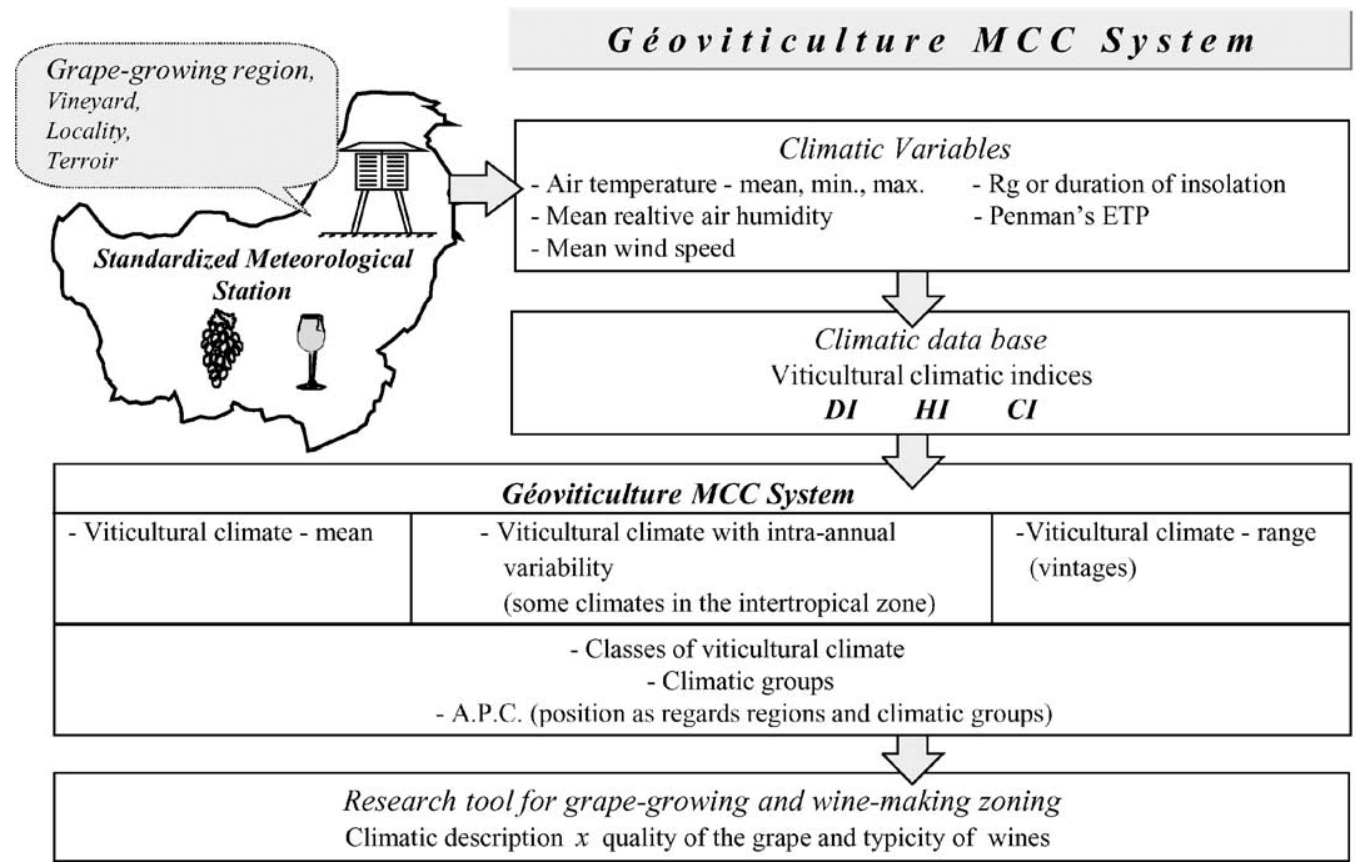

Fig. 1. Scheme showing the Géoviticulture MCC System at work.

In the case of HI, extremes are located either under cold conditions like in the northern limit of the grape (as in Canada- the CAva region or in England-the GBma region), or warm conditions in the tropical regions such as India, Thailand, Guatemala or the Brazilian Northeast. If we look at the heliothermal index, in relation to the value of the cold night index, we see a clear tendency to increase the CI values by increasing the HI. However, there is a great difference, as a function of the values of $\mathrm{HI}$ and $\mathrm{CI}$, according to region (Table 5). Let us take an example of the grape-growing regions in Argentina: the region of Lujan de Cuyo, ARlu, at an HI of 2568 , very close, therefore to that of the region of Rio Negro, ARri, with an HI of 2566. On the other hand, the $\mathrm{CI}$ is $13.2^{\circ} \mathrm{C}$ at ARlu against $8.9^{\circ} \mathrm{C}$ at ARri. These are 2 arid climates that present very different thermal conditions for ripening. At ARri night temperatures are very low, a condition which has a very marked effect on grape color. The CI thus allows a one to distinguish between the thermal climates of these two regions.

On the other hand, it becomes clear that there is a great diversity of water balance conditions in the regions as a whole, here represented by DI (Table 5).
This approach, shown by dryness index, clarifies the importance of taking the water balance component into account as an essential element of variability in characterizing the climate of a grape-growing environment. That is the case of Bento Gonçalves, located in the extreme south of Brazil (BRbe), and of Montpellier, located in the south of France (FRmp). The two regions are not different as far as $\mathrm{HI}$ and $\mathrm{CI}$ are concerned. Actually, BRbe lies in a region with a transition from the oceanic warm/subtropical type to humid summer, which is why it has a mean DI of $200 \mathrm{~mm}$. On the other hand, FRmp lies in a mediterranean-type climate, a region that is dry in summer, with an DI value of $-50 \mathrm{~mm}$. This affects the quality of grapes in potential sugar, berry color and aromatic potential.

\subsection{Application of the Géoviticulture MCC System}

Table 5 shows the application of the Géoviticulture MCC System to the 97 grape-growing regions included in the study. Montpellier (FRmp), for instance, has a viticultural climate moderately dry, temperate warm and temperate nights (for DI, HI and CI, respectively), which can be expressed by the corresponding 


\section{Géoviticulture MCC System}

\section{A. P. C. for the 3 climatic indices: $D I, H I, C I$}

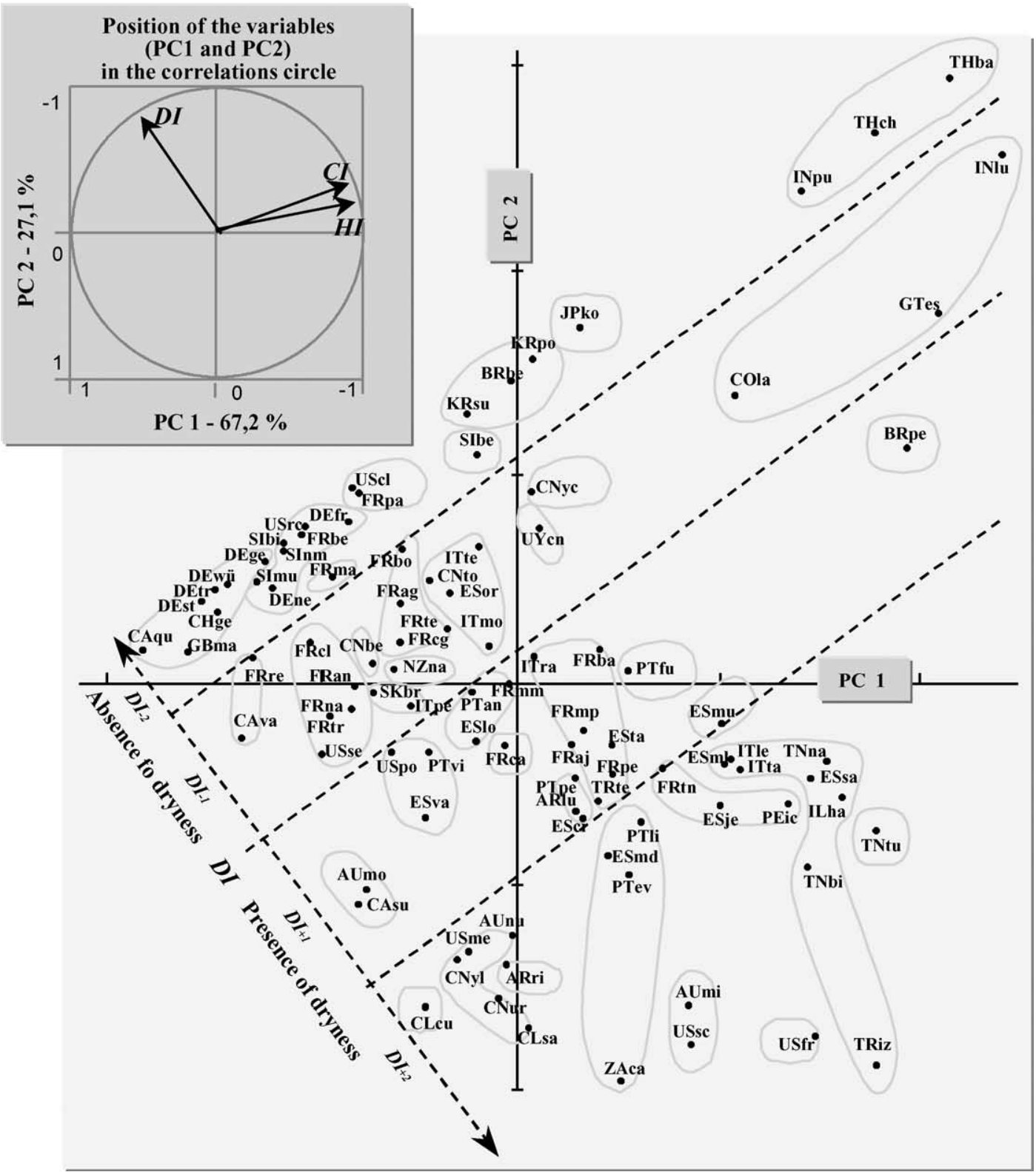

Fig. 2. Analysis of the Principal Components for the three climatic indices (HI, DI, CI) of the 97 grape-growing regions: position of the grape-growing regions and climatic groups (according outlines over the regions) pertaining to the regions according main components 1 and 2 (see acronym's legend in Table 1 and viticultural climate according Géoviticulture MCC System in Table 5). 
acronyms, i.e., viticultural climate $\mathrm{DI}+1 \mathrm{HI}+1 \mathrm{CI}-1$. The climatic description of the region might be improved by adding a fourth classification factor such as type of general climate (i.e. mediterranean).

The set of three indices with six classes for HI, four classes for CI and four classes for DI, theoretically allows a total of 96 different climatic groups. However, many of the climatic groups are not found in the viticultural climate of the regions of the globe. In the regions involved in our study, 36 groups were identified (Table 5; Fig. 2). It is important to clarify that a grape-growing region may present more than one viticultural climate, represented in our study by the climatic mean of one meteorological station of the region. Notice also that the viticultural climate may change from year to year inside the same region.

When data from the three climatic indices are processed using multivariate analysis - analysis of principal components (APC) this enables the positioning of grape-growing regions and climatic groups. APC performed with the results of the viticultural climate (mean) of the three indices-DI, HI, CI of the 97 grape-growing regions (Fig. 2), showed that the main component 1 (thermal) and 2 (water) represents $94.3 \%$ of the total variability, which reinforces the capacity to explain the variability of the viticultural climate during the growing cycle in the Géoviticulture MCC System. $\mathrm{HI}$ and $\mathrm{CI}$ are also represented in a third component (night coolness). This is interesting up to a point, especially since it shows the regions that have important differences between the CI and HI (Fig. 3; Table 5).

The climatic groups (Table 5) are represented in Fig. 2 by the outlines over the regions belonging to each group.

\subsection{The viticultural climate with intra-annual variability}

This concept may be used to classify climates of the grape-growing regions that have more than one natural vegetative cycle a year, different of the classical viticulture where we have only one vegetative cycle per year. To study this situation, let us take the example of the climate of the São Francisco River Valley, in the Northeast of Brazil, in the viticultural region of Petrolina (BRpe). This region is located at $09^{\circ} 09^{\prime}$ latitude South, in a tropical semi-arid climate zone.

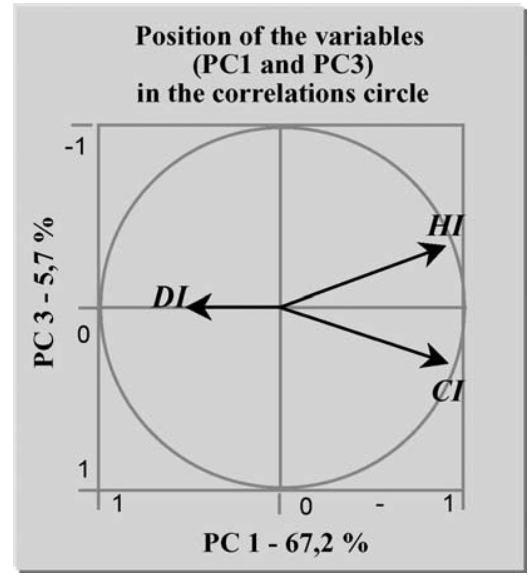

Fig. 3. Correlation circle of the analysis of the principal components for the three climatic indices (HI, DI, CI)-main components 1 and 3 .

The mean annual air temperature is $26.4^{\circ} \mathrm{C}$, with a mean of $28.3{ }^{\circ} \mathrm{C}$ for the warmest month and $24.3^{\circ} \mathrm{C}$ for the coldest month. The total annual rainfall is $559 \mathrm{~mm}$, concentrated during the December-April period. The value of the 3 indices in our study for this region is: $\mathrm{DI}=-1 \mathrm{~mm} ; \mathrm{HI}=3654$; and $\mathrm{CI}=21.3^{\circ} \mathrm{C}$. This region thus has a viticultural climate $\mathrm{DI}+1 \mathrm{HI}+3 \mathrm{CI}-2$. Its position in relation to the climatic groups and grape-growing regions as a whole is shown in Fig. 2. In order to study the viticultural climate under these conditions, the three indices are calculated for all periods of the year, by consecutive one-month steps over the classical period for the calculation of the indices being studied (BRpe). The 12 values obtained show that during the year, the climatic indices present values located at the following intervals: 51 to $-181 \mathrm{~mm}$ for DI, $3265-3669$ for $\mathrm{HI}$ and $18.1-22.2^{\circ} \mathrm{C}$ for CI.

The results represented in the APC of Fig. 4 show the position of Petrolina (BRpe) with indices calculated for 12 periods (main component 1, thermal; main component 2 , water). In order to obtain a reference to other grape-growing regions, there is also a representation of other grape-growing regions located in the Intertropical zone. Thus it is observed that the viticultural climate of BRpe changes period by period. Noticeable, above all, are the periods of BRpe09 to BRpe01, with a higher dryness index; or, on the contrary, BRpe05, DI being the lowest. Petrolina 


\section{Climatic groups in a viticultural climate with intra-annual variability}
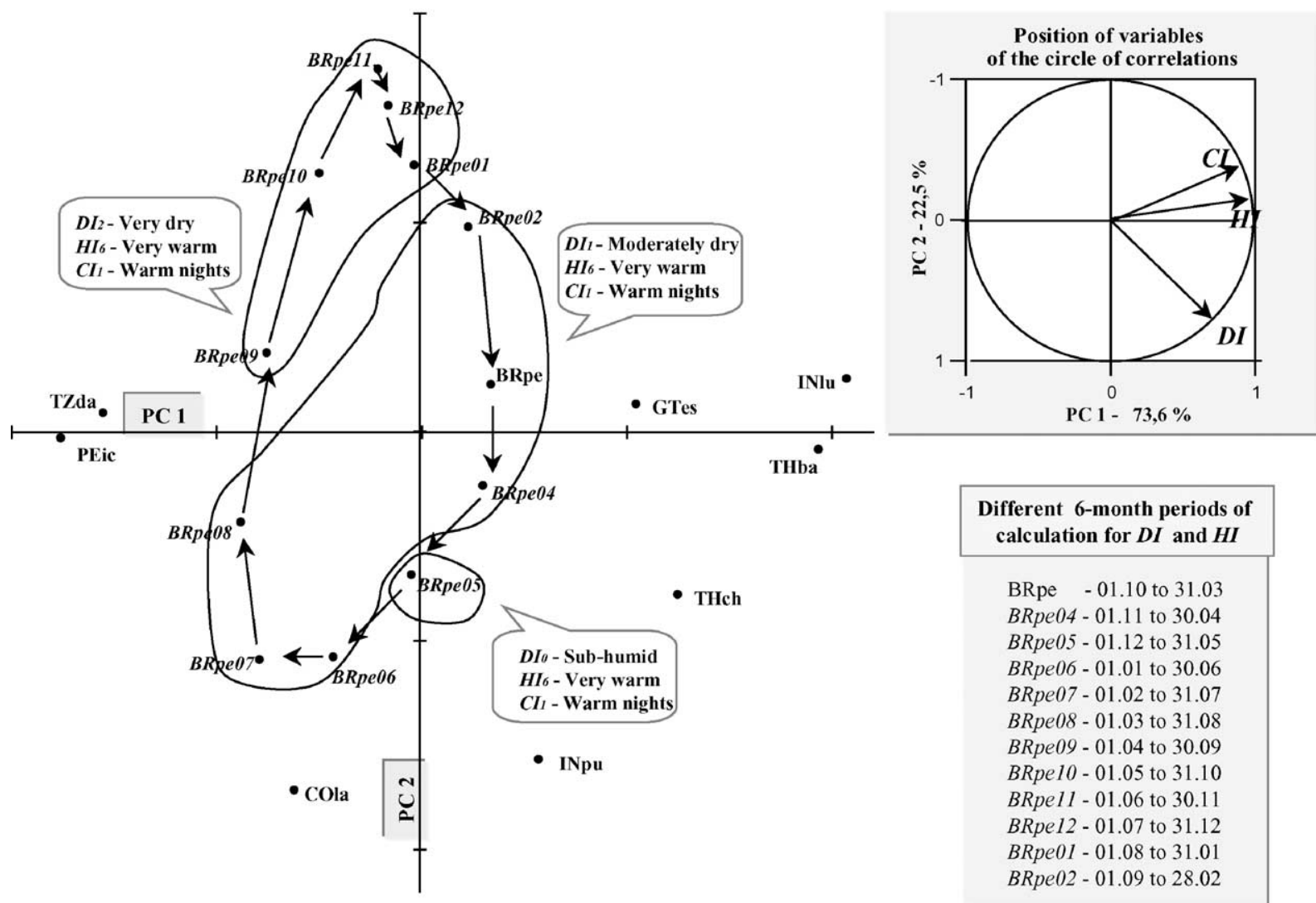

\begin{tabular}{|l|}
\hline $\begin{array}{c}\text { Different 6-month periods of } \\
\text { calculation for } \boldsymbol{D I} \text { and } \boldsymbol{H I}\end{array}$ \\
\hline BRpe -01.10 to 31.03 \\
BRpe04-01.11 to 30.04 \\
BRpe05-01.12 to 31.05 \\
BRpe06-01.01 to 30.06 \\
BRpe07 - 01.02 to 31.07 \\
BRpe08 -01.03 to 31.08 \\
BRpe09-01.04 to 30.09 \\
BRpe10 - 01.05 to 31.10 \\
BRpe11 - 01.06 to 30.11 \\
BRpe12 - 01.07 to 31.12 \\
BRpe01 - 01.08 to 31.01 \\
BRpe02 - 01.09 to 28.02 \\
\hline
\end{tabular}

Fig. 4. Example of viticultural climate with intra-annual variability in the region of Petrolina (BRpe), Brazil, a region located in the intertropical zone (tropical semi-arid climate): the APC shows that the viticultural climate changes as a function of the period of the year during which grapes can be produced (main component 1, thermal; main component 2, water).

is, thus, placed in three situations in relation to the viticultural climate: viticultural climate with very dry, very warm and warm nights (period BRpe09 to BRpe01); viticultural climate sub-humid, very warm and warm nights (period BRpe05); and viticultural climate moderately dry, very warm and warm nights for the other periods (Fig. 4). This region in fact presents three different viticultural climates, above all considering criterion DI. This condition, therefore, describes a viticultural climate with intra-annual variability, characterized by change of class as a function of the period of the year in which grapes can be produced.

\section{Discussion}

\subsection{Identifying differences in viticultural climate using multicriteria climatic indices}

The statistical study of the world-wide data base and the French data sub-base in analysis of principal components, reveals that these three indices, established as a function of a mean vegetative cycle of vines, account for over $90 \%$ of the total climatic variability in the main components 1 and 2 (Fig. 2) (Tonietto, 1999). The discrimination of classical types of climate is equally observed (Carbonneau and Tonietto, 1998). 
The results show that the heliothermal potential cannot express all of the thermal variability of an environment. There is significant climatic variability in night temperature conditions that come into play regarding the grape maturation period, with qualitative implications. That is why it is important to include index CI in the thermal characterization of the regions.

Equally, it is possible to analyze the importance of DI if, for instance, one compares two grape-growing regions with similar $\mathrm{HI}$ and $\mathrm{CI}$ values, but very different DI. Table 5 presents a whole set of examples that enable showing climatic variability as regards water balance.

The possibility offered by the Géoviticulture MCC System to analyze the viticultural climate of the regions where there are several harvests a year, or harvests at different periods during the year, is a methodology which provides a new contribution to integrate the viticulture of the regions located in the intertropical zone, as in the example of Petrolina, Brazil (Fig. 4).

\subsection{Géoviticulture MCC System for grape-growing zoning}

Macroclimatic studies using Géoviticulture MCC System of world viticulture show the major role played by climatic groups from the grape-growing regions in the acknowledged typicity of wines, as regards their organoleptic characteristics (Tonietto, 1999; Tonietto and Carbonneau, 1999). The good consistency found between the climatic groups and the characteristics of acknowledged typicity of wines from each region is also a way of validating the climatic approach presented by the Géoviticulture MCC System.

As regards to viticultural zoning, the methodology of viticultural climate description of the Géoviticulture MCC System creates the prospect of furthering climate research concerning the typicity of products at different levels on the scale (at the level of a country, a large grape-growing region or a small grape-growing region), as shown in the studies performed (Tonietto and Carbonneau, 1998, 1999; Tonietto, 1999).

To perform a classification that could be used worldwide, the Géoviticulture MCC System is made to establish the smallest possible number of classes for each viticultural climate index. This is done in order to underline the most significant differences between the climates of grape-growing regions. This means that the use of these indices to study each grape-growing region as to mesoclimate can be convenient, if one establishes sub-classes inside each reference-class of index, on the basis of the statistical variability of its own data.

For zoning studies, the HI, CI and DI range could be taken into account, here modulating the periods according to the duration of the vine cycle (for the Northern Hemisphere: final moment on 15 August or 15 October for HI and DI; 16 July-15 August or 16 September-16 October for CI). It is also possible to use the indices on the phenological events of interest-budburst to harvest for HI and DI and ripening period (veraison to harvest) for CI.

The calculated DI at the regional level is comparable from the climatic standpoint. From the viticultural standpoint, the interpretation of the DI results in a region with a very different Wo will be closer to reality, if we also take into account information available regarding the real water balance of the vines. So, Wo can be modified if a given region has a large majority of shallow soils (i.e. Wo $=100 \mathrm{~mm}$ ) or very deep soils (i.e. Wo $=300 \mathrm{~mm}$ ). Equally, for humid regions, complementary information can be obtained simulating the calculation of DI, and adopting Wo $=200 \mathrm{~mm}$ at an initial moment, but without a higher maximum of $W$ in the calculation performed month by month. Another situation concerns vineyards with irrigation practice. For this situation DI may be calculated not only using precipitation values in the formula, but introducing also the amount of irrigation water to have the potential water availability in the soil.

The System may also help study the variability of viticultural climate in different types of climate throughout the world, the study of the range of viticultural climate in the regions (inter-annual variability) and the evolution of viticultural climate as a function of climate change (Carbonneau and Tonietto, 1998; Tonietto et al., 2002). The approach also constitutes a complement of the description of the viticultural climate of vintages (millésimes) which, in their case, should add complementary climatic information to the climatic indices DI, HI and CI.

Géoviticulture MCC System may also help studies of site selection for new viticultural areas. In this situation the three indices used must be combined with others, especially those related to viticulture inaptitude or limitations like frost risk, climatic conditions 
for budbreak, disease risk, excess humidity conditions, etc.

\subsection{Géoviticulture MCC System as a reference for climate viticulture worldwide}

The method developed allows the world's grapegrowing regions as a whole to adopt this classification of their climates, based on classical climatic data from the region.

The Géoviticulture MCC System enables all the grape-growing regions worldwide together to adopt this classification in order to categorize their viticultural climates. With these 97 regions and 36 climatic groups (Table 5), a very good representation of the climatic diversity found in the world vineyards, any region can be included to obtain information regarding its position in relation to the climatic groups of world viticulture as a whole. Subsequent useful maps, with geographic information system (GIS), may be developped from de MCC System.

Also, the System may be used as reference for climate characterization of the regions in scientific and technical publications.

\section{Conclusions}

The Géoviticulture MCC System developed enables the following conclusions.

(a) It is effective to grouping grape-growing regions than the single criterion indices available.

(b) The dryness index and the cool night index make it possible to show other aspects of the climate of grape-growing regions in the world vineyards, and they are complementary to the thermal or heliothermal indices usually used (the Heliothermal Index of Huglin is the most pertinent in the Géoviticulture MCC System).

(c) The proposal of new definitions for viticultural climate (mean and range) and climatic group for grape-growing regions enables greater precision in studying the viticultural climatology.

(d) In warm climates, with more than one harvest a year, the proposed definition of viticultural climate with intra-annual variability enables the characterization of the viticultural climate throughout the year by means of this multicriteria evaluation.

(e) A very large climatic diversity found in the world's vineyards was clearly shown.

(f) The method developed allows the world's grape-growing regions as a whole to adopt this classification of their climates, based on classical climatic data from the region involved. The Géoviticulture MCC System enables positioning each region in relation to other regions and climatic groups in world viticulture, identifying homonym climates.

(g) The Géoviticulture MCC System is a research tool for grape-growing and wine-making zoning.

\section{Acknowledgements}

We thank the World Meteorological Organization (WMO), and especially Mr. N.A. Gbeckor-Kove and Mr. V.K. Sivakumar of the Department of the World Climate Program of the Division of Agricultural Meteorology. We also thank all the other institutions and people who worked to collect the data in the different countries: South Africa, South African Weather Bureau; Germany, Deutscher Wetterdienst; England, The Meteorological Office; Argentina, Instituto Nacional de Tecnologia Agropecuária; Australia, Bureau of Meteorology; Brazil, Empresa Brasileira de Pesquisa Agropecuária; Canadá, Canadian Meteorological Centre; Chile, Dirección Meteorológica de Chile; China, China Meteorological Administration and China Agricultural University; Colombia, Instituto de Hidrologia, Meteorologia y Estudios Ambientales; Spain, Instituto Nacional de Meteorologia; United States, Office of Metorology, National Weather Service and National Climatic Data Center; France, Météo-France; Guatemala, Instituto Nacional de Sismologia, Vulcanologia, Meteorologia e Hidrologia; India, India Meteorological Department; Israel, Israel Meteorological Service; Italy, European Commission, Joint Research Centre, Space Applications Institute, Agriculture and Regional Information System; Japan, Japan Meteorological Agency; New Zealand, Horticulture and Food Research Institute of New Zealand; Peru, Servicio Nacional de Meteor. e Hidrologia; Portugal, Instituto de Meteorologia; Republic of Korea, Korea Meteorological Administration; Slovakia, 
Slovak Hydrometeorological Institute; Slovenia, Hydrometeorological Institute; Switzerland, Institut Suisse de Météorologie; Tanzânia, Directorate of Meteorology; Thailand, Meteorological Department; Tunisia, Institut National de la Météorologie; Turkey, State Meteorological Service; Uruguay, Dirección Nacional de Meteorologia and Instituto Nacional de Vitivinicultura.

To our collaborators, Pierre Cour, Michel Calleja, Eric Lebon and Jean-Michel Boursiquot, for their contributions and their critical analyses of the research as a whole. To FINEP for financial support.

\section{References}

Amerine, M.A., Winkler, A.J., 1944. Composition and quality of musts and wines of California grapes. Hilgard 15, 493-673.

Bentryn, G., 1988. World climate patterns and viticulture. In: Proceedings of International Cool Climate Viticulture and Oenology. New Zealand for Viticulture and Oenology, Auckland, pp. 9-11.

Bravdo, B.-A., Hepner, Y., 1987. Irrigation management and fertigation to optimize grape composition and vine performance. In: Proceedings of the Symposium on Grapevine Canopy and Vigor Management. Acta Hortic 206, 49-67.

Carbonneau, A., 1994. Le zonage des potentialités viticoles à l'échelle de 1'Union Européenne. Progr. Agric. Vitic. 22, 505514.

Carbonneau, A., 1998. Irrigation, vignoble et produits de la vigne. In: Traité d'irrigation, Aspects qualitatifs. Paris, Lavoisier, pp. 257-276 (Chapitre IV).

Carbonneau, A., Tonietto, J., 1998. La géoviticulture: de la géographie viticole aux évolutions climatiques et technologiques à l'échelle mondiale. Rev. Oenol. Tech.Vitivin. Oenol. $87,16-18$.

Conradie, W.J., Carey, V.A., Bonnardot, V., Saayman, D., Schoor van, L.H., 2002. Effect of different environmental factors on the performance of Sauvignon blanc grapevines in the Stellenbosch/Durbanville districts of South Africa. I. geology, soil, climate, phenology and grape composition. South African J. Enol. Vitic. 23 (2), 79-91.

Coombe, B.G., 1987. Influence of temperature on composition and quality of grapes. In: Proceedings of the Symposium on Grapevine Canopy and Vigor Management. Acta Hortic. 206, 23-35.

Fregoni, C., Pezzutto, S., 2000. Principes et premières approches de l'indice bioclimatique de qualité de Fregoni. Progr. Agric. Vitic. 18, 390-396.

Galet, P., 1993. Précis de viticulture. Montpellier, Déhan, 582 pp.

Gladstones, J., 1992. Viticulture and environment. Adelaide, Winetitles, $310 \mathrm{pp}$.

Huglin, P., 1978. Nouveau mode d'évaluation des possibilites héliothermiques d'un milieu viticole. In: Proceedings of the Symposium International sur l'ecologie de la Vigne. Ministère de l'Agriculture et de l'Industrie Alimentaire, Contança, pp. 89-98.

Huglin, P., Schneider, C., 1998. Biologie et écologie de la vigne. Lavoisier, Paris, 370 pp.

Jackson, D.I., Cherry, N.J., 1988. Prediction of a district's graperipening capacity, using a latitude-temperature index (LTI). Am. J. Enol. Vitic. 1, 19-28.

Jackson, D.I., Lombard, P.B., 1993. Environmental and management practices affecting grape composition and wine quality: a review. Am. J. Enol. Vitic. 4, 409-430.

Kliewer, W.M., 1973. Berry composition of Vitis vinifera cultivars as influenced by photo and nycto-temperatures during maturation. J. Am. Soc. Hort. Sci. 2, 153-159.

Kliewer, W.M., Torres, R.E., 1972. Effect of controlled day and night temperatures on grape coloration. Am. J. Enol.Vitic. 2, 71-77.

Mérouge, I., Seguin, G., Arrouays, D., 1998. Les sols et l'alimentation hydrique de la vigne à Pomerol: état hydrique et croissance de la vigne en 1995. J. Int. Sci. Vigne Vin 32 (2), 59-68.

Peguy, C.P., 1970. Précis de climatologie. Masson, Paris, 468 pp.

Penman, H.L., 1948. Natural evaporation from open water, bare soil, and grass. Proc. R. Soc. London Ser. A 193, 120146.

Riou, Ch., Becker, N., Sotes Ruiz, V., Gomez-Miguel, V., Carbonneau, A., Panagiotou, M., Calo, A., Costacurta, A., Castro de, R., Pinto, A., Lopes, C., Carneiro, L., Climaco, P., 1994. Le déterminisme climatique de la maturation du raisin: application au zonage de la teneur em sucre dans la communauté européenne. Office des Publications Officielles des Communautés Européennes, Luxembourg, 322 pp.

Seguin, G., 1983. Influence des terroirs viticoles sur la constitution et la qualité des vendanges. Bull. O.I.V. 623, 3-18.

Singleton, V.L., Esau, P., 1969. Phenolic substances in grapes and wine, and their significance. Adv. Food Res. Supp. 1, 112133.

Smart, R.E., Dry, P.R., 1980. A climatic classification for Australian viticultural regions. Australian Grapegrower Winemaker 17 (196), 8-16.

Tomana, T., Utsunomiya, N., Dataoka, I., 1979. The effect of environmental temperatures on fruit on ripening on the tree. II. The effect of temperatures around whole vines and clusters on the coloration of 'Kyoho'grapes. J. Jap. Soc. Hort. Sci. 48, 261-266.

Tonietto, J., 1999. Les macroclimats viticoles mondiaux et l'influence du mésoclimat sur la typicité de la Syrah et du Muscat de Hambourg dans le sud de la France: méthodologie de caráctérisation. Thèse Doctorat. Ecole Nationale Supérieure Agronomique, Montpellier, $233 \mathrm{pp}$.

Tonietto, J., 2001. Valorização do ecossistema: importância da regionalização vitivinícola na produção de vinhos de qualidade. In: Annales del Congreso Latinoamericano de Viticultura y Enologia. Asociación de Enólogos del Uruguay, Montevidéu, pp. 1-9.

Tonietto, J., Carbonneau, A., 1998. Facteurs mésoclimatiques de la typicité du raisin de table de l'A.O.C., Muscat du Ventoux dans le Département de Vaucluse. Prog. Agric. Vitic. 12, 271279. 
Tonietto, J., Carbonneau, A., 1999. Análise mundial do clima das regiões vitícolase de sua influência sobre a tipicidade dos vinhos: a posição da viticultura brasileira comparada a 100 regiões em 30 países. In: Tonietto, J., Guerra, C.C. (Eds.), Anais do Congresso Brasileiro de Viticultura e Enologia, Embrapa Uva e Vinho. Bento Gonçalves, pp. 75-90.
Tonietto, J., Garrido, L.R., Sônego, O.R., 2002. Avaliação ex-ante do impacto de alterações climáticas do Complexo Energético do Rio das Antas sobre a viticultura regional. Bento Gonçalves. Embrapa, 76 pp.

Winkler, A.J., 1962. General Viticulture. University of California, Berkeley, 633 pp. 